\title{
Exposure of Common Bean Seeds to Liquid Nitrogen Modifies Mineral Composition of Young Plantlet Leaves
}

\author{
Inaudis Cejas' ${ }^{1}$ Annekathrin Rumlow ${ }^{2}$, Ariel Turcios², Florent Engelmann ${ }^{3}$, \\ Marcos Edel Martínez ${ }^{1}$, Lourdes Yabor ${ }^{1}$, Jutta Papenbrock ${ }^{2}$, José Carlos Lorenzo ${ }^{1}$ \\ ${ }^{1}$ Laboratory for Plant Breeding, Centro de Bioplantas, Universidad de Ciego de Ávila, Ciego de Ávila, Cuba \\ ${ }^{2}$ Leibniz University Hannover, Institute of Botany, Hannover, Germany \\ ${ }^{3}$ IRD, UMR DIADE, Montpellier, France \\ Email: Jutta.Papenbrock@botanik.uni-hannover.de, jclorenzo@bioplantas.cu
}

Received 13 July 2016; accepted 20 August 2016; published 23 August 2016

Copyright (C) 2016 by authors and Scientific Research Publishing Inc.

This work is licensed under the Creative Commons Attribution International License (CC BY). http://creativecommons.org/licenses/by/4.0/

(c) (i) Open Access

\begin{abstract}
Many publications describe cryopreservation techniques but only a few studies have focused on the biochemical and physiological changes occurring in plants regenerated from seeds exposed to liquid nitrogen. This paper aims at describing the effect of common bean seed cryostorage on mineral nutrition of young plantlets. The following elements were measured on leaves of 10-dayold plantlets from non-cryopreserved and cryopreserved seeds: $\mathrm{Al}, \mathrm{B}, \mathrm{Ba}, \mathrm{Ca}, \mathrm{Cd}, \mathrm{Co}, \mathrm{Cr}, \mathrm{Cu}, \mathrm{Fe}, \mathrm{K}$, $\mathrm{Mg}, \mathrm{Mn}, \mathrm{Na}, \mathrm{Ni}, \mathrm{P}, \mathrm{S}, \mathrm{Se}, \mathrm{Sr}$ and $\mathrm{Zn}$. At 10 days after sowing, both treatments (control and cryopreserved seeds) showed $100 \%$ seed germination without any visual phenotypic difference. However, contents of several elements in the leaves were different. Exposure of seeds to liquid nitrogen decreased $\mathrm{Cu}, \mathrm{Cd}$ and $\mathrm{Na}$ uptake and increased absorption of $\mathrm{B}$ and $\mathrm{Al}$. Further studies are required to understand the mechanisms underlying the relationship between seed exposure to liquid nitrogen and mineral nutrition during the early stages of plantlet growth.
\end{abstract}

\section{Keywords}

Common Bean, Cryopreservation, Cryostorage

\section{Introduction}

Legumes play a critical role in agriculture, since they are major contributors to both the human and animal diet and to the maintenance of soil fertility. The protein level in the seed of a grain legume can be as high as three 
times that in a cereal grain, and a significant proportion of the human nutritional requirements for proteins is supplied by legumes [1]. Common bean (Phaseolus vulgaris L.) is one of the world's most important grain legumes, which is consumed as dietary staple worldwide, especially in Latin America and Africa [2]. At present, our Laboratory for Plant Breeding at the University of Ciego de Avila (Cuba) is conducting a research project on $P$. vulgaris genetic improvement aiming at increasing tolerance to soil salinity and drought. We are therefore interested in using cryopreservation for long-term storage of $P$. vulgaris elite seeds.

Our group has already published two reports on cryopreservation of common beans seeds, which studied the effects of cryopreservation of seeds on early stages of germination [3] and performed a phenotypic and molecular characterization of plants from non-cryopreserved and cryopreserved seeds [4]. In the first report, which concerned the cryopreservation of $P$. vulgaris dry seeds, we noted that, during the early stages of germination, no phenotypic changes were observed visually in seedlings recovered from cryopreserved seeds [3]. However, several significant effects of seed liquid nitrogen exposure were recorded at the biochemical level, including a decrease in protein and phenolic contents and an increase in aldehyde contents in stems, and a decrease in phenolic contents in roots. In general, roots were more affected by cryostorage compared with other plant parts, while leaves were the least affected. The effects of seed cryopreservation seemed to decline progressively along with seedling growth.

In the second report, we studied if cryostorage of $P$. vulgaris L. dry seeds (12\% moisture content) induced variations in regenerated plants at the phenotypic and molecular levels [4]. No statistically significant phenotypic differences were observed for the parameters measured in plants of the first and the second generation. Across both treatments, about $76 \%$ of the seeds germinated 10 days after sowing. The genetic analyses performed on the second generation plants using six nuclear Simple Sequences Repeats (SSR) markers revealed no changes in microsatellite length between control and cryopreserved samples, implying that there was no effect of seed liquid nitrogen exposure on genome integrity. The phenotypic and molecular results reported confirmed that cryostorage was an efficient and reliable technique to conserve $P$. vulgaris seeds and regenerate true-to-type plants.

This paper aims at providing more data about the impact of cryostorage on mineral nutrition of young common bean plantlets. We hypothesized that seeds subjected to low temperature stress produce seedlings with changed mineral nutrition. The following elements were measured on leaves of 10-day-old plantlets from noncryopreserved and cryopreserved seeds: Al, B, Ba, Ca, Cd, Co, Cr, Cu, Fe, K, Mg, Mn, Na, Ni, P, S, Se, Sr and $\mathrm{Zn}$. To our knowledge, such information has not been published to date on seeds. In the literature, many publications describe cryopreservation techniques [5]-[11]. By contrast, only few studies have been carried out on the understanding of the biochemical and physiological changes occurring after liquid nitrogen exposure of seeds [3] [4] [12]-[16].

\section{Materials and Methods}

After harvesting, a selection procedure to rule out unqualified seeds of $P$. vulgaris L. cv. Buschbohnen Hilds Maxi was performed. Seeds with $12 \%$ moisture content (fresh weight basis [17]) were stored at $4^{\circ} \mathrm{C}$ in the dark in hermetically closed glass containers. There was not any pretreatment for the seeds before the experiment.

One group of seeds was immersed in liquid nitrogen for one week and another (control) was maintained in the dark at $4^{\circ} \mathrm{C}$, for 7 days too. Recovery of seeds from liquid nitrogen was performed according to Stanwood and Bass [18] by placing them at room temperature $\left(20^{\circ} \mathrm{C}\right)$ for $2 \mathrm{~h}$. From each treatment, 30 seeds ( 3 replicates of 10 seeds each) were randomly selected for germination in a growth climatic chamber $\left(500 \mathrm{~cm}^{3}\right.$ pots; Profi substrate, Einheits, Erde ${ }^{\circledR}$ Classic; $150 \mu \mathrm{mol} \cdot \mathrm{m}^{-2} \cdot \mathrm{s}^{-1}$; $9 \mathrm{~h} \mathrm{light} / 15 \mathrm{~h}$ dark; $20^{\circ} \mathrm{C}$; irrigation: $25 \mathrm{~mL}$ distilled water per day). Ten days after sowing, when plantlets showed newly-formed leaves, mineral contents of new leaves were determined.

For the elemental analytical measurements of plant material, pooled samples of each biological replicate were measured at least three times and up to six times. Dry plant material was ground to fine powder (MM 400 grinder, Retsch GmbH, Haan, Germany). About $38 \mathrm{mg}$ of the ground powder was incinerated for a minimum of $8 \mathrm{~h}$ in a muffle furnace at $480^{\circ} \mathrm{C}$ (M104, Thermo Fisher Scientific Corporation, Waltham, Massachusetts, USA) for each treatment. After cooling the samples to room temperature (between $21^{\circ} \mathrm{C}$ and $23^{\circ} \mathrm{C}$ ), $1.5 \mathrm{ml} 66 \%$ nitric acid was added. After $10 \mathrm{~min}, 13.5 \mathrm{ml}$ of ultra-pure water was added. The solutions were filtered ( $0.45 \mu \mathrm{m}$ pore size, Carl Roth, Karlsruhe, Germany) and stored in vials at $4^{\circ} \mathrm{C}$ before final analysis. The samples were analyzed by 
inductively coupled plasma optical emission spectrometry (ICP-OES) (iCAP 6000 ICP Spectrometer, Thermo Fisher Scientific Corporation). Precautions were used to avoid inadvertent contamination of plant materials with micronutrients-i.e. plastic forceps were used. The growth chamber was isolated from other soil samples.

The SPSS software (Version 8.0 for Windows, SPSS Inc.) was used to perform t-tests and compare results of the two treatments studied: non-cryopreserved and cryopreserved seeds $(p \leq 0.05)$. The overall coefficients of variation (OCV) were calculated as follows: (standard deviation/average)*100. In this formula, we considered the average values of non-cryopreserved and cryopreserved seeds to calculate the standard deviation and average of the two treatments. Therefore, the higher the difference between the two materials compared, the higher the OCV [19].

\section{Results and Discussion}

At 10 days after sowing, both treatments showed $100 \%$ seed germination without any visual phenotypic difference. Germination progress curves, i.e. germination rate, were the same (data not shown). However, contents in several elements in leaves were different (Table 1). According to the highest OCVs, the most important changes in the mineral uptake can be summarized as follows. Exposure of seed to liquid nitrogen decreased $\mathrm{Cu}, \mathrm{Cd}$ and Na uptake and increased absorption of $\mathrm{B}$ and $\mathrm{Al}$; although no symptom of deficiency or excess was recorded in our experiment.

Table 1. Mineral composition of common bean plantlets derived from non-cryopreserved or cryopreserved seeds that were measured by ICP-OES (iCAP6000, Thermo, USA). The amounts of the elements are expressed as $\mathrm{mg}^{-1} \mathrm{~g}^{-1} \mathrm{dry}$ mass, representing the mean of three biological replicates*.

\begin{tabular}{|c|c|c|c|}
\hline Elements & $\begin{array}{l}\text { Plantlets from non-cryopreserved seeds } \\
\text { (seed storage: } 4^{\circ} \mathrm{C} \text { ) }\end{array}$ & $\begin{array}{l}\text { Plantlets from cryopreserved seeds } \\
\text { (seed storage: liquid nitrogen) }\end{array}$ & $\mathrm{OCV}^{* *}$ \\
\hline $\mathrm{Cu}$ & $0.02711 \mathrm{a}$ & $0.00024 \mathrm{~b}$ & 138.89 \\
\hline $\mathrm{Cd}$ & 0.00018 a & $0.00005 \mathrm{~b}$ & 84.68 \\
\hline $\mathrm{Na}$ & 0.98925 a & $0.30417 \mathrm{~b}$ & 74.90 \\
\hline B & $0.14762 \mathrm{~b}$ & 0.29625 a & 47.35 \\
\hline $\mathrm{Al}$ & $0.05633 \mathrm{~b}$ & 0.09402 a & 35.45 \\
\hline $\mathrm{Cr}$ & 0.00143 a & $0.00111 \mathrm{~b}$ & 17.44 \\
\hline Co & $0.00099 \mathrm{~b}$ & 0.00126 a & 16.56 \\
\hline Mn & $0.04571 \mathrm{~b}$ & 0.05261 a & 9.92 \\
\hline $\mathrm{Zn}$ & $0.04220 \mathrm{a}$ & $0.03809 \mathrm{~b}$ & 7.25 \\
\hline S & 3.27476 a & $2.95605 \mathrm{~b}$ & 7.23 \\
\hline $\mathrm{Sr}$ & $0.02362 \mathrm{~b}$ & 0.02585 a & 6.37 \\
\hline $\mathrm{Ca}$ & 10.40949 a & $9.65243 \mathrm{~b}$ & 5.33 \\
\hline $\mathrm{Ni}$ & $0.00947 \mathrm{~b}$ & 0.01003 a & 4.07 \\
\hline K & $37.47734 \mathrm{~b}$ & 39.11943 a & 3.03 \\
\hline $\mathrm{Fe}$ & $0.14381 \mathrm{~b}$ & 0.14907 a & 2.54 \\
\hline $\mathrm{Mg}$ & 0.87934 a & $0.85078 \mathrm{~b}$ & 2.33 \\
\hline $\mathrm{Ba}$ & $0.01100 \mathrm{~b}$ & 0.01126 a & 1.66 \\
\hline $\mathrm{P}$ & $9.19244 \mathrm{~b}$ & 9.27608 a & 0.64 \\
\hline Se & Not detectable & Not detectable & - \\
\hline
\end{tabular}

*Results with the same letter are not statistically different (t-test, $p>0.05)$. ${ }^{*}$ Overall coefficient of variation $=($ Standard deviation/Average)*100. To calculate this coefficient, average values were considered. The higher difference between the two seed storages compared, the higher the overall coefficient of variation. 
$\mathrm{Cu}$ is associated with enzymes involved in redox reactions being reversibly oxidized from $\mathrm{Cu}^{+}$to $\mathrm{Cu}^{2+}$, such as those enzymes related to electron transfer during the light reactions of photosynthesis [20]. The initial symptom of $\mathrm{Cu}$ deficiency is the production of dark green leaves, which may contain necrotic spots. The necrotic spots appear first at the tips of the young leaves and then extend toward the leaf base along the margins. The leaves may also be twisted or malformed. Under extreme Cu deficiency, leaves may abscise prematurely [21].

$\mathrm{Cd}$ is a toxic heavy metal that enters the environment through various anthropogenic sources, and inhibits plant growth and development. Cd toxicity may result from a disturbance in plant metabolism as a consequence of a disturbance in the uptake and translocation of mineral nutrients. Plant nutrients, such as N, P, K, Mg, Zn; and Cd compete for the same transporters and, therefore, the presence of Cd results in mineral nutrient deficiency. The optimization of mineral nutrient supply under Cd stress could reduce Cd toxicity by greater availability of minerals at the transport sites, resulting in reduced accumulation of $\mathrm{Cd}$, and could also alleviate Cd-induced toxic effects by enhancing biochemical reactions and physiological processes in plants [22]. Our group has speculated that it would be possible to assess a changed capability of the cryo-treated seed to tolerate growth on Cd containing soils.

Although generally regarded as toxic to plants, some species, such as C4 and CAM, require Na ions for carbon fixation. In these plant species, $\mathrm{Na}$ appears vital for regenerating phosphoenolpyruvate and under Na deficiency, these plants exhibit chlorosis and necrosis, or even fail to form flowers. Many species also benefit from exposure to low levels of $\mathrm{Na}$ ions. Na stimulates growth through enhanced cell expansion, and it can partly substitute for potassium as an osmotically active solute [23].

Although the precise function of B in plant metabolism is unclear, evidence suggests that it plays roles in cell elongation, nucleic acid synthesis, hormone responses, and membrane function. B deficient plants may exhibit a wide variety of symptoms, depending on the species and on the age of the plant. A characteristic symptom is black necrosis of the young leaves and terminal buds. The necrosis of the young leaves occurs primarily at the base of the leaf blade. Stems may be unusually stiff and brittle. Apical dominance may also be lost, causing the plant to become highly branched; however, the terminal apices of the branches soon become necrotic due to the inhibition of cell divisions [24]. Structures such as fruits, fleshy roots, and tubers may exhibit necrosis or abnormalities related to the breakdown of internal tissues [25].

Due to the toxic effects of $\mathrm{Al}$, acid soils with high levels of soluble Al generally restrict plant growth [26]. It has been reported that $\mathrm{Al}$ inhibits the uptake of nutrients [27], disrupts the functions of the plasma membrane [28] or cell walls [29], and forms a complex with intracellular substances in roots. By contrast, however, there are several reports indicating that $\mathrm{Al}$ has a beneficial effect on plant growth. This seems to be especially true for native plant species that are adapted to acid soils [30].

As discussed above, $\mathrm{Cu}, \mathrm{Cd}, \mathrm{Na}, \mathrm{B}$ and $\mathrm{Al}$ are important micronutrients for plants and their concentration in 10-day-old plantlet leaves was drastically modified by seed exposure to liquid nitrogen (Table 1). However, these absorption modifications had no effect at the phenotype level on 10-day-old plantlets. These modifications may be transient because, when studying the field performance of common bean plants derived from cryopreserved seeds, no nutrition deficiencies were recorded [4]. Substantial contributions of worldwide research groups are still required to understand the mechanisms underlying the relationship between liquid nitrogen seed exposure and mineral nutrition at early stages of plantlet growth.

To end we would like to clarify some limitations of our research. There is no evidence of seedling changes at $10 \mathrm{~d}$ of growth. Therefore, a single determination of mineral content (10 d) may miss broadly similar contents in control and cryo-seeds over the growth period. On the other hand, we do not know for sure if the concentrations measured are within the normal range for common bean seedlings. Moreover, in a previous work, we found biochemical differences between the roots of plants derived from cryopreserved and non-cryopreserved seeds which could be related to the results reported here.

\section{Acknowledgements}

This research was supported by the Institute of Botany (Leibniz University of Hannover) and the Bioplant Centre (University of Ciego de Avila, Cuba). This research was also partially supported by the German Academic Exchange Service (DAAD) through a grant to Dr. José Carlos Lorenzo Feijoo.

\section{References}

[1] Gepts, P., Beavis, W., Brummer, E., Shoemaker, R., Stalker, H., Weeden, N. and Young, N. (2005) Legumes as a 
Model Plant Family. Genomics for Food and Feed Report of the Cross Legume Advances through Genomics Conference. Plant Physiology, 137, 1228-1235. http://dx.doi.org/10.1104/pp.105.060871

[2] FAOSTAT (2013) Statistical Database of the Food and Agriculture of the United Nations. FAO, Rome.

[3] Cejas, I., Vives, K., Laudat, T., González-Olmedo, J., Engelmann, F., Martínez-Montero, M.E. and Lorenzo, J.C. (2012) Effects of Cryopreservation of Phaseolus vulgaris L. Seeds on Early Stages of Germination. Plant Cell Reports, 31, 2065-2073. http://dx.doi.org/10.1007/s00299-012-1317-x

[4] Cejas, I., Méndez, R., Villalobos, A., Palau, F., Aragón, C., Engelmann, F., Carputo, D., Aversano, R., Martínez, M.E. and Lorenzo, J.C. (2013) Phenotypic and Molecular Characterization of Phaseolus vulgaris Plants from Non-Cryopreserved and Cryopreserved Seeds. American Journal of Plant Sciences, 4, 844-849.

http://dx.doi.org/10.4236/ajps.2013.44103

[5] Berjak, P., Bartels, P., Benson, E., Harding, K., Mycock, D., Pammenter, N. and Sershen, W. (2010) Cryoconservation of South African Plant Genetic Diversity. In Vitro Cellular \& Developmental Biology_Plant, 47, 65-81. http://dx.doi.org/10.1007/s11627-010-9317-4

[6] Engelmann, F. (2000) Importance of Cryopreservation for the Conservation of Plant Genetic Resources. In: Engelmann, F. and Takagi, H., Eds., Cryopreservation of Tropical Plant Germplasm-Current Research Progress and Applications, JIRCAS, Tsukuba, 8-20.

[7] Engelmann, F. (2004) Plant Cryopreservation: Progress and Prospects. In Vitro Cellular \& Developmental BiologyPlant, 40, 427-433. http://dx.doi.org/10.1079/IVP2004541

[8] Engelmann, F. (2010) Use of Biotechnologies for the Conservation of Plant Biodiversity. In Vitro Cellular \& Developmental Biology —Plant, 47, 5-16. http://dx.doi.org/10.1007/s11627-010-9327-2

[9] Engelmann, F. and Takagi, H. (2000) Cryopreservation of Tropical Plant Germplasm. In: Engelmann, F. and Takagi, H., Eds., Cryopreservation of Tropical Plant Germplasm-Current Research Progress and Applications, JIRCAS, Tsukuba, 496.

[10] Forni, C., Braglia, R., Beninati, S., Lentini, A., Ronci, M., Urbani, A., Provenzano, B., Frattarelli, A., Tabolacci, C. and Damiano, C. (2010) Polyamine Concentration, Transglutaminase Activity and Changes in Protein Synthesis during Cryopreservation of Shoot Tips of Apple Variety Annurca. CryoLetters, 31, 413-425.

[11] Salinas-Flores, L., Adams, S., Wharton, D., Downes, M. and Lim, M. (2008) Survival of Pacific Oyster, Crassostrea gigas, Oocytes in Relation to Intracellular Ice Formation. Cryobiology, 56, 28-35. http://dx.doi.org/10.1016/j.cryobiol.2007.10.172

[12] Harding, K., Marzalina, M., Krishnapillay, B., Nashatul, Z., Normah, M. and Benson, E. (2000) Molecular Stability Assessments of Trees Regenerated from CRyopreserved Mahogany (Swietenia macrophylla King.) Seed Germplasm Using Non-Radioactive Techniques to Examine the Chromatin Structure and DNA Methylation Status of the Ribosomal RNA Genes. Journal of Tropical Forest Science, 12, 149-163.

[13] Lakhanpaul, S., Babrekar, P. and Chandel, K. (1996) Monitoring Studies in Onion (Allium cepa L.) Seeds Retrieved from Storage at $-2^{\circ} \mathrm{C}$ and $-18^{\circ} \mathrm{C}$. CryoLetters, 17, 219-232.

[14] Uragami, A., Lucas, M., Ralambosoa, J., Renard, M. and Dereuddre, J. (1993) Cryopreservation of Microspore Embryos of Soilseed Rape (Brassica napus) by Dehydration in Air with or without Alginate Encapsulation. CryoLetters, 14, 83-90.

[15] Zevallos, B., Cejas, I., Valle, B., Yabor, L., Aragón, C., Engelmann, F., Martínez, M.E. and Lorenzo, J.C. (2013) Short-Term Liquid Nitrogen Storage of Wild Tomato (Solanum lycopersicum Mill.) Seeds Modifies the Levels of Phenolics in 7 Day-Old Seedlings. Scientia Horticulturae, 160, 264-267. http://dx.doi.org/10.1016/j.scienta.2013.06.002

[16] Zevallos, B., Cejas, I., Rodríguez, R.C., Yabor, L., Aragón, C., González, J., Engelmann, F., Martínez, M.E. and Lorenzo, J.C. (2013) Biochemical Characterization of Ecuadorian Wild Solanum lycopersicum Mill. Plants Produced from Non-Cryopreserved and Cryopreserved Seeds. CryoLetters, 34, 413-421.

[17] ISTA (2005) International Rules for Seed Testing International Seed Testing Association. Bassersdorf, Switzerland.

[18] Stanwood, P. and Bass, L. (1981) Seed Germplasm Preservation Using Liquid Nitrogen. Seed Science and Technology, 9, 423-437.

[19] Lorenzo, J.C., Yabor, L., Medina, N., Quintana, N. and Wells, V. (2015) Coefficient of Variation Can Identify the Most Important Effects of Experimental Treatments. Notulae Botanicae Horti Agrobotanici Cluj-Napoca, 43, $287-291$. http://dx.doi.org/10.15835/nbha.43.1.9881

[20] Haehnel, W. (1984) Photosynthetic Electron Transport in Higher Plants. Annual Review of Plant Biology, 35, $659-693$. http://dx.doi.org/10.1146/annurev.pp.35.060184.003303

[21] Arnon, D.I. and Stout, P.R. (1939) The Essentiality of Certain Elements in Minute Quantity for Plants with Special 
Reference to Copper. Plant Physiology, 14, 371-375. http://dx.doi.org/10.1104/pp.14.2.371

[22] Nazar, R., Iqbal, N., Masood, A., Khan, M., Syeed, S. and Khan, N. (2012) Cadmium Toxicity in Plants and Role of Mineral Nutrients in Its Alleviation. American Journal of Plant Sciences, 3, 1476-1489. http://dx.doi.org/10.4236/ajps.2012.310178

[23] Johnstone, M., Grof, C.P.L. and Brownell, P.F. (1988) The Effect of Sodium Nutrition on the Pool Sizes of Intermediates of the C Photosynthetic Pathway. Australian Journal of Plant Physiology, 15, 749-760. http://dx.doi.org/10.1071/PP9880749

[24] Shelp, B.J. (1993) Physiology and Biochemistry of Boron in Plants. In: Gupta, U.C., Ed., Boron and Its Role in Crop Production, CRC Press, Boca Raton, 53-85.

[25] Mengel, K. and Kirkby, E.A. (1987) Principles of Plant Nutrition. International Potash Institute, Worblaufen-Bern, Switzerland.

[26] Matsumoto, H. (2000) Cell Biology of Aluminum Toxicity and Tolerance in Higher Plants. International Review of Cytology, 200, 1-46. http://dx.doi.org/10.1016/S0074-7696(00)00001-2

[27] Huang, J.W., Shaff, J.E., Grunes, D.L. and Kochian, L.V. (1992) Aluminum Effects on Calcium Fluxes at the Root Apex of Aluminium-Tolerant and Aluminium-Sensitive Wheat Cultivars. Plant Physiology, 98, 230-237. http://dx.doi.org/10.1104/pp.98.1.230

[28] Matsumoto, H., Yamamoto, Y. and Kasai, M. (1992) Changes of Some Properties of the Plasma Membrane-Enriched Fraction of Barley Roots Related to Aluminum Stress: Membrane-Associated ATPase, Aluminum and Calcium. Journal of Soil Science and Plant Nutrition, 38, 411-419. http://dx.doi.org/10.1080/00380768.1992.10415073

[29] Blamey, F.P.C. and Dowling, A.J. (1995) Antagonism between Aluminium and Calcium for Sorption by Calcium Pectate. Plant and Soil, 171, 137-140. http://dx.doi.org/10.1007/BF00009576

[30] Aniol, A. (1984) Induction of Aluminum Tolerance in Wheat Seedlings by Low Doses of Aluminum in the Nutrient Solution. Plant Physiology, 75, 551-555. http://dx.doi.org/10.1104/pp.76.3.551

\section{Submit or recommend next manuscript to SCIRP and we will provide best service for you:}

Accepting pre-submission inquiries through Email, Facebook, LinkedIn, Twitter, etc.

A wide selection of journals (inclusive of 9 subjects, more than 200 journals)

Providing 24-hour high-quality service

User-friendly online submission system

Fair and swift peer-review system

Efficient typesetting and proofreading procedure

Display of the result of downloads and visits, as well as the number of cited articles

Maximum dissemination of your research work

Submit your manuscript at: http://papersubmission.scirp.org/ 